\begin{tabular}{|c|c|c|}
\hline BIODIK & $\begin{array}{c}\text { BIODIK: Jurnal IImiah Pendidikan Biologi } \\
\text { ISSN 2580-0922 (online), ISSN 2460-2612 (print) } \\
\text { Volume 6, Nomor 04, Tahun 2020, Hal. 562-569 } \\
\text { Available online at: } \\
\text { https://online-journal.unja.ac.id/biodik }\end{array}$ & BIODIK \\
\hline
\end{tabular}

Research Article

open Access

\title{
Analisis Komponen Penyusun Lembar Kerja Peserta Didik Uji Golongan Darah Sistem ABO
}

\author{
(Analysis of Component Compiler of Student Worksheet for ABO System Blood Type Test) \\ Muhammad Vikram*, Bambang Supriatno, dan Sri Anggraeni \\ Universitas Pendidikan Indonesia \\ JI. Dr. Setiabudhi Nomor 229 Bandung-Indonesia \\ ${ }^{*}$ Corresponding Author : muhammadvikram007@gmail.com
}

\begin{tabular}{|c|c|}
\hline Informasi Artikel & ABSTRACT \\
\hline $\begin{array}{l}\text { Submit: } 28-05-2020 \\
\text { Diterima: } 14-08-2020 \\
\text { Dipublikasikan: } 19-12-2020\end{array}$ & $\begin{array}{l}\text { Practicum is an activity that aims to enable students to carry out experiments to prove } \\
\text { phenomena based on theories obtained in learning. Practicum refers to the student } \\
\text { worksheet (LKPD). The purpose of this study was to analyze and describe the } \\
\text { conceptual, practical, and knowledge construction components of the ABO blood } \\
\text { group test students' worksheets which are used as a basis for making improvements } \\
\text { and reconstruction of LKPD. The research method is descriptive qualitative. Sampling } \\
\text { was done by purposive sampling with a total of } 5 \text { LKPDs. The LKPD trial was carried } \\
\text { out at the UPI physiology laboratory. The instruments used in this research are } \\
\text { according to the Vee diagram and the structural analysis instruments developed. The } \\
\text { results showed that the conceptual component was in accordance with the demands } \\
\text { of the curriculum. Practical components such as work steps, object recording, and } \\
\text { standard operating procedure (SOP) activities need to be repaired and reconstructed. } \\
\text { The knowledge construction component is quite good and needs repair and } \\
\text { reconstruction. So it can be concluded that the LKPD of the ABO system blood group } \\
\text { test needs to be reconstructed } \\
\text { Keywords: LKPD, Structure Analysis, ABO system blood group test. }\end{array}$ \\
\hline Penerbit & ABSTRAK \\
\hline $\begin{array}{l}\text { Program Studi Pendidikan } \\
\text { Biologi, Fakultas Keguruan dan } \\
\text { IImu Pendidikan, Universitas } \\
\text { Jambi-Indonesia }\end{array}$ & $\begin{array}{l}\text { Praktikum merupakan suatu kegiatan yang bertujuan agar siswa dapat melakukan } \\
\text { percobaan untuk membuktikan fenomena-fenomena berdasarkan teori yang } \\
\text { didapatkan di dalam pembelajaran. Praktikum mengacu kepada lembar kerja peserta } \\
\text { didik (LKPD). Tujuan dalam penelitian ini adalah untuk menganalisis dan } \\
\text { mendeskripsikan kompenen konseptual, praktikal, dan kontruksi pengetahuan lembar } \\
\text { kerja peserta didik uji golongan darah sistem ABO yang digunakan sebagai dasar } \\
\text { untuk melakukan perbaikan dan rekontruksi LKPD. Metode penelitian adalah } \\
\text { deskriptif kualitatif. Pengambilan sampel dilakukan dengan cara purposive sampling } \\
\text { dengan total LKPD sebanyak } 5 \text { buah. Uji coba LKPD dilakukan di laboratorium } \\
\text { fisiologi UPI. Instrumen yang digunakan dalam penilitian ini menurut diagram Vee } \\
\text { dan Instrumen analisis struktur yang dikembangkan. Hasil penelitian menunjukkan } \\
\text { bahwa komponen konseptual sudah sesuai dengan tuntutan kurikulum. Komponen } \\
\text { praktikal seperti langkah kerja, perekaman objek, dan standar operasional prosedur } \\
\text { (SOP) kegiatan perlu diperbaiki dan direkontruksi kembali. Komponen kontruksi } \\
\text { pengetahuan sudah cukup baik dan perlu perbaikan dan rekontruksi. Sehingga dapat } \\
\text { disimpulkan bahwa LKPD uji golongan darah sistem ABO perlu direkontruksi } \\
\text { kembali. } \\
\text { Katakunci: LKPD,Analisis Struktur, uji golongan darah sistem ABO. }\end{array}$ \\
\hline
\end{tabular}

This BIODIK : Jurnal IImiah Pendidikan Biologi is licensed under a CC BY-NC-SA (Creative Commons Attribution-ShareAlike 4.0 International License) 


\section{PENDAHULUAN}

Praktikum adalah suatu kegiatan yang menonjol di sekolah dalam pembelajaran Sains (Millar, 2001). Praktikum merupakan salah satu bentuk usaha untuk menguji, mengaplikasikan, atau pembuktian ilmiah dari suatu teori yang didapatkan dalam pembelajaran. Dalam hal komponen praktikum sekolah, praktikum adalah kegiatan belajar mengajar sains di mana siswa, yang bekerja secara individu atau kelompok kecil, mengamati dan memanipulasi objek atau bahan yang mereka pelajari (Millar, 2009). Wellington (1998) berpendapat bahwa kerja praktek sains sekolah dapat digunakan oleh guru sebagai ilustrasi fenomena, memberikan siswa perasaan untuk fenomena tersebut atau sebagai latihan atau langkah yang harus diikuti untuk mengembangkan keterampilan tertentu.

Praktikum sangat penting dilakukan, dalam kegiatan praktikum baik guru maupun siswa menaruh harapan tinggi terhadap kegiatan tersebut (Widodo dan Ramdhaningsih, 2006). Dengan adanya kegiatan praktikum siswa akan lebih paham tentang konsep yang dipelajari, meningkatkan motivasi, berkembangkannya keterampilan hands on dan mind on, dan tumbuhnya sikap ilmiah yang didapatkan berdasarkan pengalaman-pengalaman dalam melakukan kegiatan praktikum. Kegiatan praktikum dapat memberikan kesan yang utuh dan lebih bermakna kepada siswa, karena dalam kegiatan praktikum siswa cenderung berkerja dengan melibatkan indera (Supriatno, 2009).

Kegiatan praktikum yang dilakukan oleh siswa umumnya mengacu kepada Desain Kegiatan Laboratorium (DKL), desain tersebut berisi tentang langkah kerja operasional yang memandu siswa dalam melaksanakan kegiatan praktikum di laboratorium (Supriatno, 2009). Desain Kegiatan Laboratorium tersebut di muat dalam bentuk lembar kerja peserta didik (LKPD). LKPD merupakan salah satu cara untuk mempermudah siswa dalam memahami materi, meningkatkan keterlibatan siswa dalam proses pembelajaran dan memberikan kesempatan penuh kepada siswa untuk mengembangkan proses berpikirnya (Amanda et.al, 2020). LKPD berisi tentang pedoman tentang apa yang akan dilakukan oleh siswa dalam kegiatan praktikum. LKPD yang baik hendakknya terdiri dari komponen berikut, yaitu (1) tujuan praktikum, (2) pendahuluan (berupa landasan teori), (3) alat dan bahan, (4) langkah kerja, (5) cara perangkaian alat, (6) interpretasi data hasil pengamatan, (7) analisis data, dan (8) kesimpulan (Rustaman dan Wulan, 2007).

LKPD merupakan salah satu komponen penting dalam kegiatan praktikum. Akan tetapi banyak LKPD yang prosedur praktikum tidak sesuai, pertanyaan yang ditanyakan dalam praktikum hanya berupa teori tanpa mengaitkan dengan kegiatan praktikum. Hal ini mengakibatkan makna dari praktikum itu hilang dan menyebabkan praktikum itu hanya membuang-buang waktu saja (tidak bermakna). Oleh karena itu pentingnya untuk meninjau kembali lembar kerja siswa sebelum diberikan pada kegiatan praktikum. Terdapat 3 komponen utama dalam meninjau LKPD antara lain: (1) analisis konseptual, (2) analisis praktikal, (3) analisis kontruksi pengetahuan. Analisis konseptual bertujuan untuk menganalisis kesesuaian kegiatan laboratorium dengan kurikulum yang berlaku. Analisis praktikal bertujuan untuk menguji 
keterlaksaan kegiatan laboratorium. Analisis kontruksi pengetahuan bertujuan untuk menganalisis apakah pertanyaan di dalam LKPD sudah membentuk pengetahuan yang didapatkan dari kegiatan praktikum dan penarikan kesimpulan berdasarkan tujuan kegiatan praktikum.

Salah satu LKPD yang dianalisis adalah uji golongan darah sistem $A B O$ untuk kelas XI IPA pada materi sistem sirkulasi. Terdapat beberapa pertimbangan mengapa LKPD uji golongan darah sistem $A B O$ perlu ditinjau dan direkontruksi berdasarkan hasil uji coba dan wawancara kepada guru, yakni (1) prosedur kegiatan praktikum masih miss (Kurang tepat) dan tidak terdapat prosedur keselamatan kerja, (2) pertanyaan praktikum hanya teori saja sehingga tanpa melakukan kegiatan praktikum pun siswa dapat menjawab pertanyaan tersebut. Studi ini memberikan gambaran tentang mengenai LKPD uji golongan darah sistem ABO mengenai tujuan, proses, fakta yang muncul, dan pertanyaan dalam LKPD. Hal ini dapat digunakan sebagai rujukan dalam memodifikasi dan merekontruksi LKPD dalam rangka memperbaiki kualitas proses kegiatan praktikum uji golongan darah sistem ABO.

\section{METODE PENELITIAN}

Metode yang digunakan dalam penelitian ini adalah metode deskriptif kualitatif. Sampel LKPD yang diambil secara purposive sampling. Pengambilan sampel dilakukan dengan cara purposive sampling dengan total LKPD sebanyak 5 buah LKPD uji golongan darah sistem ABO dari berbagai sumber yang terdapat di dalam buku paket (2 buah), LKPD buatan guru (1 buah), LKPD yang diterbitkan (1 buah), dan LKPD dari sumber internet (1 buah). Uji coba LKPD dilakukan di laboratorium Fisiologi Universitas Pendidikan Indonesia. penelitian ini menggunakan dua instrumen yaitu instrumen diagram Vee dan instrumen analisis struktur. Komponen yang dianalisis antara lain (1) analisis konseptual, (2) analisis praktikal, dan (3) analisis kontruksi pengetahuan. Adapun rubrik skor diagram Vee disajikan pada Tabel 1.

Tabel 1. Rubrik skor diagram Vee

\begin{tabular}{|c|c|}
\hline \multicolumn{2}{|c|}{ Focus Question } \\
\hline 0 & Tidak ada focus question yang teridentifikasi. \\
\hline 1 & Focus question teridentifikasi tetapi tidak memandu perolehan event/konsep. \\
\hline 2 & $\begin{array}{l}\text { Focus question teridentifikasi; memandu perolehan event/konsep; terdapat event yang salah sehingga } \\
\text { menghasilkan data yang salah. }\end{array}$ \\
\hline 3 & Focus question teridentifikasi dan dapat digunakan untuk menghasilkan event dan data yang sesuai. \\
\hline \multicolumn{2}{|r|}{ Object/Event } \\
\hline 0 & Tidak ada object/event yang teridentifikasi. \\
\hline 1 & Event utama teridentifikasi tetapi tidak konsisten dengan focus question. \\
\hline 2 & Event utama teridentifikasi dan konsisten dengan focus question. \\
\hline 3 & Event utama teridentifikasi; konsisten dengan focus question; dapat digunakan untuk merekam data. \\
\hline \multicolumn{2}{|r|}{ Teori/Prinsip/Konsep } \\
\hline 0 & Tidak ada konsep yang teridentifikasi. \\
\hline 1 & Konsep teridentifikasi tetapi tanpa prinsip dan teori. \\
\hline 2 & $\begin{array}{l}\text { Konsep teridentifikasi dan terdapat salah satu prinsip (konseptual/prosedural); atau konsep dan teori yang } \\
\text { relevan teridentifikasi. }\end{array}$ \\
\hline 3 & $\begin{array}{l}\text { Konsep dan prinsip (konseptual dan prosedural) teridentifikasi; atau konsep, salah satu prinsip dan teori yang } \\
\text { relevan teridentifikasi. }\end{array}$ \\
\hline
\end{tabular}


$4 \quad$ Konsep dan prinsip (konseptual dan prosedural) serta teori yang relevan teridentifikasi.

\begin{tabular}{cl}
\hline Record/Transformasi & Tidak ada record/transformasi yang teridentifikasi. \\
\hline 0 & Record teridentifikasi tetapi tidak konsisten dengan focus question/event. \\
2 & Salah satu (record/transformasi) teridentifikasi dan konsisten dengan focus question/event. \\
3 & Record/transformasi teridentifikasi; record sesuai event; transformasi tidak konsisten dengan focus question. \\
4 & Record dan transformasi teridentifikasi; record sesuai dengan event; transformasi konsisten dengan focus \\
& question; dan kegiatan lab sesuai dengan level siswa. \\
\hline Knowledge claim & Tidak ada Knowledge claim yang teridentifikasi. \\
\hline & Knowledge claim tidak berhubungan dengan konsep, prinsip, dan teori. \\
2 & Knowledge claim meliputi konsep yang dapat digunakan untuk mengenerelasikan tetapi tidak konsisten dengan \\
3 & Knowd dan transformasi. \\
& Kan transformasi. \\
4 & Knowledge claim meliputi konsep yang dapat digunakan untuk mengenerelasikan; konsisten dengan record dan \\
& transformasi; dapat digunakan untuk membuat focus question baru.
\end{tabular}

\section{HASIL DAN PEMBAHASAN}

\section{Analisis Konseptual}

Bagian ini bertujuan untuk menganalisis kesesuaian kegiatan laboratorium dengan kurikulum. Data hasil analisis konseptual mengacu pada instrumen analisis struktur disajikan pada Tabel 2.

Tabel 2. Analisis konseptual LKPD uji golongan darah sistem ABO

\begin{tabular}{clllllll}
\hline \multirow{2}{*}{ No } & \multicolumn{2}{c}{ Parameter } & \multicolumn{5}{c}{ LKPD } \\
\cline { 3 - 7 } & & 1 & 2 & 3 & 4 & 5 \\
\hline 1 & Kesesuaian konten dengan KD & $\sqrt{ }$ & $\sqrt{ }$ & $\sqrt{ }$ & $\sqrt{ }$ & $\sqrt{ }$ \\
2 & Kesesuaian judul dengan kegiatan & $\sqrt{ }$ & $\sqrt{ }$ & $\sqrt{ }$ & $\sqrt{ }$ & $\sqrt{ }$ \\
3 & Kesesuaian tujuan dengan langkah kerja & $\sqrt{ }$ & $\sqrt{ }$ & $\sqrt{ }$ & $\sqrt{ }$ & $\sqrt{ }$ \\
4 & Kesesuaian kegiatan dengan tingkat kognitif siswa & $\sqrt{ }$ & $\sqrt{ }$ & $\sqrt{ }$ & $\sqrt{ }$ & $\sqrt{ }$ \\
\hline
\end{tabular}

Berdasarkan Tabel 2, konten dalam praktikum ini sudah sesuai dengan KD. Tuntutan KD 4.7 edisi kurtilas sebelum revisi: Melakukan pengamatan bentukbentuk dan menghitung jumlah sel darah dan melakukan tes golongan darah masing-masing siswa, dengan beberapa keterampilan yang akan diperoleh siswa setelah melakukan kegiatan ini, yaitu (1) Keterampilan menggunakan alat dan bahan, (2) keterampilan melakukan observasi, (3) menginterpretasikan data hasil percobaan, dan (4) menyimpulkan percobaan berdasarkan data yang didapatkan. Tujuan dari praktikum ini sudah sesuai dengan tuntutan KD, yaitu hanya sedekar melakukan uji golongan darah dan menentukan golongan darah masing-masing siswa dengan tingkat kognitif yang dituntut C1-C3. Kesesuaian tujuan dengan langkah kerja sudah sesuai dengan langkah kerja yang akan di eksekusi oleh siswa.

\section{Analisis Praktikal}

Kegiatan ini bertujuan untuk menguji keterlaksanaan kegiatan secara laboratorium dalam menghadirkan objek/fenomena. Data hasil analisis praktikal mengacu pada instrumen analisis struktur disajikan pada Tabel 3. 
Tabel 3. Analisis Praktikal LKPD uji golongan darah sistem ABO

\begin{tabular}{cllllll}
\hline \multirow{2}{*}{ No } & \multicolumn{2}{c}{ Parameter } & \multicolumn{5}{c}{ LKPD } \\
\cline { 3 - 7 } & & 1 & 2 & 3 & 4 & 5 \\
\hline 1 & Apakah alat-alatnya sesuai dengan standar/tersedia sekolah & $\sqrt{ }$ & $\sqrt{ }$ & $\sqrt{ }$ & $\sqrt{ }$ & $\sqrt{ }$ \\
2 & Apakah bahan praktikum dapat disediakan dengan mudah & - & - & - & - & - \\
3 & Apakah langkah-langkahnya terstruktur & - & - & - & - & - \\
4 & Apakah setiap langkah dapat dieksekusi tanpa kesulitan & $\sqrt{ }$ & $\sqrt{ }$ & $\sqrt{ }$ & $\sqrt{ }$ & $\sqrt{ }$ \\
5 & Apakah objek/fenomenanya muncul & $\sqrt{ }$ & $\sqrt{ }$ & $\sqrt{ }$ & $\sqrt{ }$ & $\sqrt{ }$ \\
6 & Apakah objek/fenomena mudah diamati & $\sqrt{ }$ & $\sqrt{ }$ & $\sqrt{ }$ & $\sqrt{ }$ & $\sqrt{ }$ \\
7 & Apakah ada perekaman data & $\sqrt{ }$ & - & - & $\sqrt{ }$ & $\sqrt{ }$ \\
8 & Bagaimana bentuk perekaman objek/fenomena & $\sqrt{ }$ & - & - & $\sqrt{ }$ & $\sqrt{ }$ \\
9 & Apakah objek fenomena relevan dengan judul/tujuan & $\sqrt{ }$ & $\sqrt{ }$ & $\sqrt{ }$ & $\sqrt{ }$ & $\sqrt{ }$ \\
10 & Adakah petunjuk safety lab & - & - & - & - & - \\
11 & Prosedurnya tepat & - & - & - & - & - \\
\hline
\end{tabular}

Berdasarkan Tabel 2, hasil analisis kelima LKPD hampir menunjukkan hasil yang sama. Yang membedakan adalah ada atau tidaknya perekaman data dan bagaimana bentuk perekaman data dalam LKPD. Selain itu prosedur langkah kerja kurang tepat yang mengakibatkan praktikum menjadi kurang efektif. Apabila siswa mengerjakan langkah kerja yang tidak terstruktur ataupun ambigu (membingungkan) maka dapat mengakibatkan kegagalan dalam proses kegiatan praktikum yang dilakukan. Kegagalan ini dikarenakan tidak diperolehnya data yang diharapkan untuk membantu siswa dalam menyimpulkan. Apabila prosedur kegiatan salah, maka pada dasarnya siswa belajar pengetahuan yang salah dan hal ini dapat memicu timbulnya miskonsepsi bagi siswa (Suprianto, 2009). Menurut Millar (2004) (dalam Laelasari dan Supriatno, 2018) keefektifan suatu kerja praktikum dapat diukur dari segi (1) prosedur kegiatan, yakni berkaitan dengan apa yang dikerjakan siswa, dan (2) hasil kerja praktikum, dalam hal ini berkaitan dengan apa yang dipelajari siswa. Efektivitas langkah kerja yang dimaksud merupakan terlaksananya langkah/ prosedur kerja dalam desain kegiatan laboratorium dan juga dapat menghasilkan data/fakta yang diharapkan.

Satu komponen yang sangat penting dalam kegiaatan praktikum adalah standar operasional prosedur kerja di laboratorium. Standar operasional prosedur kerja di laboratorium adalah petunjuk atau pedoman yang menunjukkan bagaimana laboran harus bersikap dengan benar dalam melakukan tindakan di laboratorium. Standar operasional prosedur atau disingkat SOP dalam sebuah laboratorium sangat diperlukan dalam upaya membentuk sistem pelayanan dan pengelolaan laboratorium yang ideal. Dari kelima LKPD yang dianalisis, tidak ada satu LKPD pun yang menuliskan tentang prosedur keselamatan, hal ini sangat fatal terutama pada praktikum uji golongan darah. Contoh dalam uji golongan darah siswa harusnya siswa menggunakan 1 jarum blood lancet 1 siswa dan setelah menggunakan harus segera dibuang. Hal ini ditakutkan ketika tidak ada prosedur keselamatan kerja praktikum, siswa menggunakan 1 jarum blood lancet dan digunakan bersama. 


\section{Analisis Kontruksi Pengetahuan}

Tahap ini adalah proses kontruksi pengetahuan, yang idealnya dibentuk berdasarkan objek/fenomena yang muncul, pencatatan dan transformasi digunakan untuk mengkontruksi pengetahuan. Data hasil analisis kontruksi pengetahuan mengacu pada Skor Diagram Vee disajikan pada Tabel 4.

Tabel 4. Skor Diagram Vee LKPD uji golongan darah sistem ABO

\begin{tabular}{|c|c|c|c|c|c|c|}
\hline \multirow{2}{*}{ No } & \multirow{2}{*}{ Diagram Vee } & \multicolumn{5}{|c|}{ Skor LKPD } \\
\hline & & 1 & 2 & 3 & 4 & 5 \\
\hline 1 & Focus questions & 1 & 1 & 2 & 2 & 1 \\
\hline 2 & Objec / Event & 2 & 2 & 2 & 2 & 2 \\
\hline 3 & Teori/Prinsip/Konsep & 2 & 3 & 3 & 3 & 2 \\
\hline 4 & Record/Transformasi & 3 & 3 & 2 & 3 & 2 \\
\hline 5 & Knowledge claim & 2 & 2 & 3 & 3 & 3 \\
\hline & Jumlah & 10 & 11 & 12 & 13 & 10 \\
\hline
\end{tabular}

Kontruksi pengetahuan dalam praktikum diimplementasikan dalam bentuk pertanyaan-pertanyaan dalam LKPD. Pertanyaan harus dibuat sesuai dengan tujuan dan dapat mengukur tingkat keberhasilan belajar (Rustaman et. al, 2003). Menurut Hasibuan \& Moedjiono (2008) (dalam Laelasari dan Supriatno, 2018) bahwa suatu pertanyaan pada dasarnya ditujukan untuk: (1) membantu siswa belajar, (2) menstimulasi siswa dalam mengembangkan kemampuan berpikir (3) memandu interaksi belajar dan kemandirian (4) meningkatkan kemampuan higher order thinking skill, dan (5) membantu pencapaian ujuan pelajaran. Dengan demikian maka pertanyaan yang disajikan dalam suatu desain kegiatan laboratorium hendaknya mengarah pada pencapaian tujuan dan mengukur ketercapain hasil dari proses laboratorium yang dilakukan.

Berdasarkan tabel 4, Focus questions dengan skor 2 (Focus question teridentifikasi, memandu perolehan event/konsep terdapat event yang salah sehingga menghasilkan data yang salah) sebanyak $40 \%$, Skor 1 (Focus question teridentifikasi tetapi tidak memandu perolehan event/konsep) sebanyak $60 \%$, maka dapar diartikan bahwa dari kelima LKPD sebanyak tiga LKPD, focus question tidak memandu peroleh event/konsep dalam praktikum.

Objek/Event dengan skor 2 (Event utama teridentifikasi dan konsisten dengan focus question) Sebanyak $100 \%$, maka dapat diartikan bahwa peristiwa utama disertai dengan objek dapat diidentifikasi dan konsisten dengan focus question. Teori/prinsip/ konsep yang dimunculkan dalam pertanyaan dengan skor 3 (Konsep dan prinsip (konseptual dan prosedural) teridentifikasi atau konsep, salah satu prinsip dan teori yang relevan teridentifikasi) sebanyak $60 \%$, maka dapat diartikan bahwa kontruksi pengetahuan relevan dengan focus question dan objec/event. Skor 2 (Konsep teridentifikasi dan terdapat salah satu prinsip (konseptual/prosedural) atau konsep dan teori yang relevan teridentifikasi) sebanyak $40 \%$, maka dapat diartikan bahwa kontruksi pengetahuan tidak relevan terbentuknya sebuah kontruksi pengetahuan siswa dalam praktikum uji golongan darah $\mathrm{ABO}$ 
Record/transformasi dengan skor 3 (Record/transformasi teridentifikasi; record sesuai event; transformasi tidak konsisten dengan focus question) sebanyak $60 \%$, skor 2 (Salah satu (record/transformasi) teridentifikasi dan konsisten dengan focus question/event) sebanyak 40\%. Knowledge claim dengan skor 3 (Knowledge claim meliputi konsep yang dapat digunakan untuk mengenerelasikan dan konsisten dengan record dan transformasi) sebanyak $60 \%$, skor 2 (Knowledge claim meliputi konsep yang dapat digunakan untuk mengenerelasikan tetapi tidak konsisten dengan record dan transformasi) sebanyak $40 \%$.

Hasil analisis menegaskan bahwa komponen pertanyaan yang ada dalam LKPD harus sesuaian dengan proses yang dilakukan dan tujuan yang ingin dicapai, sehingga siswa dapat menjawab pertanyaan yang tercantum melalui data yang didapatkan. pertanyaan yang ada hendaknya dapat menuntun siswa pada pokok persoalan, dan dapat dijawab oleh siswa. Menurut Millar \& Abraham (2009) bahwa pertanyaan fokus harus dinyatakan dengan jelas dan akurat agar kegiatan laboratorium dapat berjalan sesuai kurikulum. Dalam hal ini pertanyaan dapat digunakan untuk mengukur ketercapaian proses dan tujuan, menuntun praktikan untuk memahami konsep yang dipelajari dan mengarahkan praktikan untuk membuat suatu kesimpulan yang tepat.

\section{KESIMPULAN}

Berdasarkan data dan hasil analisis kelima LKPD uji golongan darah sistem sudah cukup baik. Akan tetapi untuk menyempurnakan dan memperbaiki LKPD tersebut perlu dilakukan rekontruksi LKPD. Adapun komponen yang harus di perbaiki antara lain: Tujuan praktikum, dasar teori, SOP dalam melakukan kegiatan praktikum, Langkah kerja praktikum, perekaman data, dan pertanyaan praktikum yang terdiri dari fakta, konsep, prinsip, dan teori untuk membangun pengetahuan peserta didik.

\section{DAFTAR PUSTAKA}

Abraham, I. (2009). Does practical work really motivate? A study of the affective value of practical work in secondary school science. International Journal of Science Education

Amanda, M. Haryani, S. Mahatmanti, W. And Marsini. (2020). Analisis kemampuan metakognisi siswa melalui penggunaan lembar kerja siswa berbasis discovery learning. Jurnal inovasi pendidikan kimia

Laelasari, I and Supriatno, B. (2018). Analisis komponen desain kegiatan laboratorium bioteknologi. Jurnal Bioedukatika

Miller et.al (2003). Measurement Of Von Willebrand Fator Activity : relative effects of ABO Blood Type and Race. Journal Of Trombosis and homeostatis 
Millar, Robin. (2001). Teaching and learning science through practical work. University of York.

Millar, R and Abrahams, I. (2009). Practical work: making it more effective. Getting Pracitical.

edumedi, D.T. Thomas. (2017). Practical Work Activities as a Method of Assessing Learning in Chemistry Teaching. EURASIA Journal of Mathematics Science and Technology Education.

Rustaman, N., Dirdjosoemarto, S., Yudianto, S. A., Achmad, Y., Subhekti, R., Rochintaniawati, D., \& Nurjhani, M. (2003). Strategi belajar mengajar biologi. Malang: UM Press. Google Scholar

Rustaman, A., \& Wulan, A. R. (2007). Kegiatan laboratorium dalam pembelajaran biologi. Jakarta: Universitas Terbuka. Google Scholar

Supriatno, B. (2009). Uji langkah kerja laboratorium biologi sekolah. dalam Proseding Seminar Nasional Jurusan Pendidikan Biologi. Bandung: Universitas Pendidikan Indonesia.

Widodo, A and Ramndaningsih, V. (2006). Analisis Kegiatan Praktikum Biologi di SMP dengan Menggunakan Video. Universitas Pendidikan Indonesia. Google Scholar. 